\title{
Electrode Function (pH Response) of Potash-Silica Glasses
}

\author{
By Donald Hubbard
}

\begin{abstract}
The electrode function ( $\mathrm{pH}$ response) of a series of potash-silica $\left(\mathrm{K}_{2} \mathrm{O}-\mathrm{SiO}_{2}\right)$ glasses was determined and a comparison made with the hygroscopicity of the glasses. All the $\mathrm{K}_{2} \mathrm{O}-\mathrm{SiO}_{2}$ glasses investigated showed a very high hygroscopicity, with an accompanying sensitive $\mathrm{pH}$ response. However, between $\mathrm{pH} 2$ and 4, glasses of 71.8 and 73.6 percent $\mathrm{SiO}_{2}$ gave $\mathrm{pH}$ response values higher than the 59 millivolts per $\mathrm{pH}$ predictable from the Nernst equation.

Electrodes prepared from all members of the series demonstrated large voltage departures from the straight-line relation with increasing alkalinity of the buffer solutions. For a glass of 75.76 percent $\mathrm{SiO}_{2}$ content, the voltage departures were compared with the chemical durability of the glass and also with the sodium-ion concentration, $\left[\mathrm{Na}^{+}\right]$, of the BrittonRobinson universal buffer solutions used. The voltage departures correlated with the magnitude of the attack much more convincingly than with the $\mathrm{pNa}$.

For several chosen $\mathrm{pH}$ values, the voltage departures for the electrodes of these glasses when plotted with reference to their $\mathrm{SiO}_{2}$ content gave curves that indicated a sharp change in slope near 74 percent of silica. A corresponding change in slope was also shown by the hygroscopicity-percentage-silica curve.
\end{abstract}

\section{Introduction}

The suitability of a glass for use in measuring the hydrogen-ion activity of aqueous solutions in accord with the dictates of the simplified Nernst equation, $\Delta E=0.000198 T \mathrm{pH}$, appears to be determined largely by two properties of the glass, namely, its water sorption (hygroscopicity) and the uniformity of its chemrcal durability when immersed in solutions varying in $\mathrm{pH}$ over an extended range. The absence of adequate hygroscopicity of the glass results in electrodes of high resistance whose $\mathrm{pH}$ responses fall appreciably below the theoretical value $[1,2,3],{ }^{1}$ whereas conditions that cause changes in the chemical

\footnotetext{
${ }^{1}$ Figures in brackets indicate the literature references at the end of this
} paper.

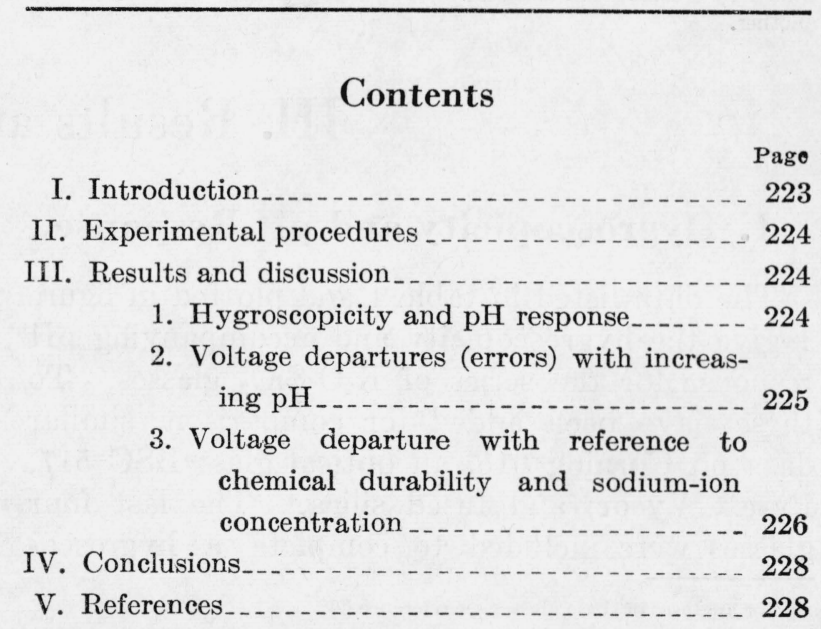

IV. Conclusions 
durability of the glass are accompanied by voltage departures $[4,5]$ that are roughly proportional to the magnitude of the change in durability [6]. In addition to the above electrical characteristics, some glasses under special conditions are believed to show specific equilibrative responses to ions other than hydrogen $[7 ; 1$, p. 267].

In the present investigation, a limited series of potash-silica $\left(\mathrm{K}_{2} \mathrm{O}-\mathrm{SiO}_{2}\right)$ glasses was studied with respect to each of the above properties.

\section{Experimental Procedures}

The hygroscopicity values were obtained by exposing powdered samples of the glasses to the high humidity furnished by a saturated solution of $\mathrm{CaSO}_{4} .2 \mathrm{H}_{2} \mathrm{O}$ thermostated in an air bath at $25^{\circ} \mathrm{C}$. The glass samples were prepared by repeated crushing, in a steel mortar, and sieving through a Tyler standard 150-mesh sieve. Each sample consisted of approximately 1.5 grams of glass that had passed the sieve. ${ }^{2}$ The samples were exposed in shallow weighing bottles for 1 and 2-hour periods. The resulting hygroscopicity values for the glasses are reported in terms of known factors, namely, weight of water sorbed times the density of the glass divided by the weight of the sample.

The humidity chamber consisted of a modified glass desiccator whose base was filled with the $\mathrm{CaSO}_{4} \cdot 2 \mathrm{H}_{2} \mathrm{O}$ solution. To hasten equilibrium and maintain uniformity, a small fan was mounted through a lucite bearing in the top of the vessel, and the inner walls were lined with a wick made from blotting paper.

The electromotive-force measurements were made with a Beckman $\mathrm{pH}$ meter, Laboratory Model G. Although the sensitivity of this instru-

2 The results of a series of experiments, not reported here, indicate that reproducibility by this method of sample preparation is equal to that obtained by crushing and using a fraction passing one sieve and retained by another. ment decreases for electrodes with resistances greater than 500 megohms, this was not a contributing factor to the results obtained on the $\mathrm{K}_{2} \mathrm{O}-\mathrm{SiO}_{2}$ series because all the electrodes from these glasses exhibited low resistance. The glass electrodes were blown as thin-walled bulbs on the end of tubing made from the experimental glasses, ${ }^{3}$ and the inner electrical connection was obtained by filling the bulb with mercury [8].

The chemical durability measurements were made by the interferometer method $[5,6,9]$. In order to have the results directly comparable with the work reported in the previous publications, the Britton-Robinson buffer mixtures [10] were used, and the temperature was maintained at $80^{\circ} \mathrm{C} \pm 0.2^{\circ}$. Durability measurements for a particular composition, and for the $\mathrm{pH}$ range covered were made on a single specimen of glass, which was reground and repolished after each test.

The glasses were prepared by C. A. Faick and analyzed by F. W. Glaze [11]. Glasses of $\mathrm{SiO}_{2}$ content lower than 71.83 percent were very unstable as electrodes, and those containing over 83.07 percent were not made because of the high melting point, high viscosity, and consequent difficulty of fining.

3 Tubes of the experimental glasses were drawn by Thomas R. Tait, of the Bureau's glassblowing shop.

\section{Results and Discussion}

\section{Hygroscopicity and pH Response}

The data listed in table 1 and plotted in figure 1 give the hygroscopicity and accompanying $\mathrm{pH}$ response for the series of $\mathrm{K}_{2} \mathrm{O}-\mathrm{SiO}_{2}$ glasses. To these have been added for comparison, similar data on Corning 015, an optical glass BSC 517, Pyrex, Vycor, and fused silica. ${ }^{4}$ The last four glasses were included to complete a hygrosco-

\footnotetext{
4 For analyses of these glasses see reference [2].
}

picity-pH-response series [3]. For the $\mathrm{K}_{2} \mathrm{O}-\mathrm{SiO}_{2}$ glasses the hygroscopicity was very high, and the electrodes prepared from them had a correspondingly sensitive $\mathrm{pH}$ response. However, the glasses, of 71.8 and 73.6 percent $\mathrm{SiO}_{2}$, although very sensitive, showed drifting voltages which gave rise to spurious $\mathrm{pH}$ responses, greater than those predictable from the Nernst equation. The electrodes from other members of the $\mathrm{K}_{2} \mathrm{O}-\mathrm{SiO}_{2}$ series gave steady readings that very closely approxi- 


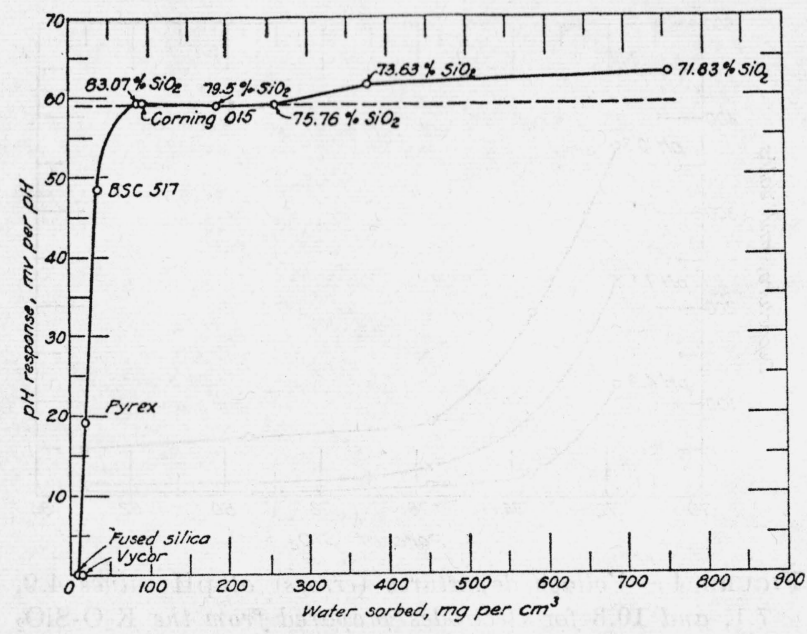

Figure 1.-The water sorbed (hygroscopicity) and accompanying $\mathrm{pH}$ response of a series of $\mathrm{K}_{2} \mathrm{O}-\mathrm{SiO}_{2}$ glasses, Corning 015, BSC 51\%, Pyrex, Vycor, and fused silica.

Values are plotted from columns 4 and 5 of table 1 . The broken line indicates the "ideal" voltage response $(59 \mathrm{mv})$ at $25^{\circ} \mathrm{C}$.

mated the theoretical $\mathrm{pH}$ response. It should not be overlooked that the shift indicated in the $\mathrm{pH}$ response-hygroscopicity curve (fig. 1) comes approximately at the same percentage composition at which breaks in the density [11] and hygroscopicity curves [2] have been reported on the same set of glasses.

TABLE 1.-Hygroscopicity (water sorbed) and $\mathrm{pH}$ response of $\mathrm{K}_{2} \mathrm{O}-\mathrm{SiO}_{2}$ glasses compared with Corning 015 and some glasses of low hygroscopicity

[The $\mathrm{pH}-$-response data were obtained below $\mathrm{pH} 4.5$ to avoid the voltage departures which accompany durability shifts at higher $\mathrm{pH}$ values. Values in italics are greater than the theoretical]

\begin{tabular}{|c|c|c|c|c|c|c|}
\hline \multicolumn{2}{|c|}{ Glasses } & \multicolumn{2}{|c|}{$\begin{array}{l}\text { Water sorbed } \\
\text { after- }\end{array}$} & \multicolumn{2}{|c|}{$\mathrm{pH}$ response- } & \multirow{2}{*}{ Remarks } \\
\hline $\mathrm{K}_{2} \mathrm{O}$ & $\mathrm{SiO}_{2}$ & $1 \mathrm{hr}$ & $2 \mathrm{hr}$ & $\begin{array}{c}\text { When } \\
\text { prepared }\end{array}$ & $\begin{array}{l}\text { After } \\
24 \mathrm{hr}\end{array}$ & \\
\hline $\begin{array}{r}\text { Percent } \\
28.17\end{array}$ & $\begin{array}{r}\text { Percent } \\
71.83\end{array}$ & $\begin{array}{r}\mathrm{mg} / \mathrm{cm}^{3} \\
240\end{array}$ & $\begin{array}{r}\mathrm{mg} / \mathrm{cm}^{3} \\
755\end{array}$ & $\begin{array}{c}m v / \mathrm{pH} \\
63.0\end{array}$ & $\begin{array}{c}m v / \mathrm{pH} \\
66.7\end{array}$ & Drifting \\
\hline 26.37 & 73.63 & 126 & 375 & 61.4 & 65.5 & Do. \\
\hline 24. 24 & 75.76 & 102 & 259 & 58.9 & 59.3 & Steady. \\
\hline 20.50 & 79.50 & 87 & 186 & 58.5 & 58.9 & Do. \\
\hline 19.01 & 80.99 & & & 59.3 & Failed & Do. \\
\hline 16. 93 & 83.07 & 46 & 91 & 59.3 & ... do & Do. \\
\hline \multicolumn{2}{|c|}{ Corning 015} & 54 & 94 & 59.2 & 59.4 & Do. \\
\hline \multirow{3}{*}{\multicolumn{2}{|c|}{$\begin{array}{l}\text { BSC 517 } \\
\text { Pyrex (chemical } \\
\text { ware) }\end{array}$}} & 25 & 36 & 48.3 & 50.4 & Sluggish. \\
\hline & & & & & & \\
\hline & & 17 & 22 & 18.8 & 19.1 & Do. \\
\hline \multicolumn{2}{|c|}{ Vycor-..... } & 14 & 17 & (1) & (1) & \\
\hline \multicolumn{2}{|c|}{ Fused silica. } & 11 & 12 & (1) & (1) & \\
\hline
\end{tabular}

${ }_{1}$ Developed no definite $\mathrm{pH}$ response.
All these electrodes failed in a few days, some after standing for less than 24 hours in distilled water.

Undoubtedly $\mathrm{K}_{2} \mathrm{O}-\mathrm{SiO}_{2}$ glasses of silica content higher than 83 percent would continue to show decreasing hygroscopicity and would follow the $\mathrm{pH}$-response-hygroscopicity curve toward fused silica, the end member of the series.

\section{Voltage Departures (Errors) With Increasing $\mathbf{p H}$}

Voltage departures were determined over an extended $\mathrm{pH}$ range on electrodes prepared from the $\mathrm{K}_{2} \mathrm{O}-\mathrm{SiO}_{2}$ glasses and Corning 015 , using the Beckman glass electrode as the reference electrode. If the reference electrode and the experimental electrode had similar $\mathrm{pH}$ response, i. e., followed the Nernst equation, the emf would remain constant over the entire $\mathrm{pH}$ range. Any deviations from constancy are considered due to errors in $\mathrm{pH}$ response of the experimental electrode and are reported in table 2 as voltage departures (errors). The measurements were taken in the buffer sequence, acid to alkaline, followed immediately by the reverse, in order to ascertain the reversibility of the electrodes and to check the effect of their immediate previous history. [12]. The

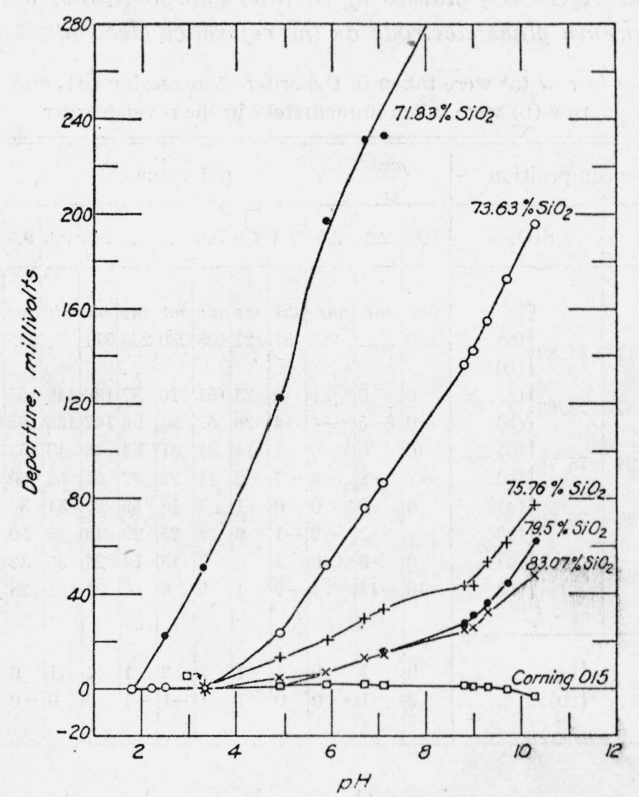

Frgure 2.-Voltage departures (errors) of electrodes prepared from a series of $\mathrm{K}_{2} \mathrm{O}-\mathrm{SiO}_{2}$ glasses and Corning 015, using the Beckman glass electrode as the reference electrode.

Values plotted are from table 2 and are the data obtained in the pH sequence, acid to alkaline. 


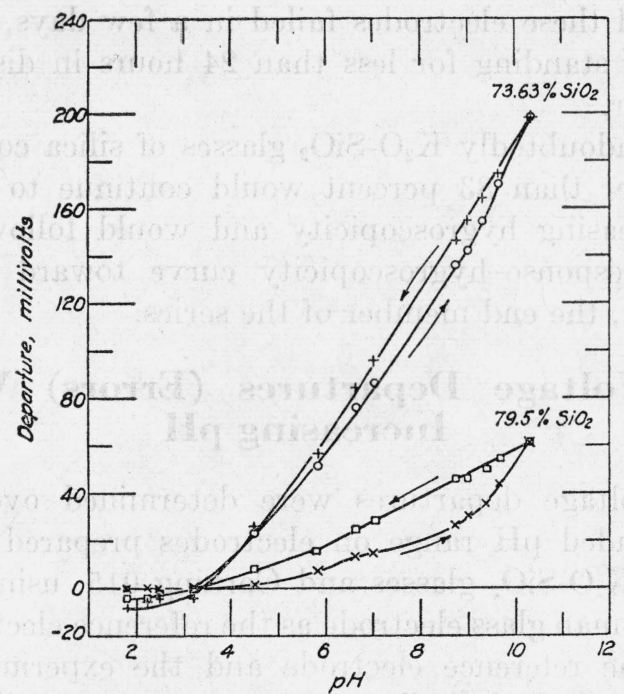

Figure 3.-Voltage departures (errors) of electrodes prepared from two $\mathrm{K}_{2} \mathrm{O}-\mathrm{SiO}_{2}$ glasses.

These curves are typical and illustrate the irreversibility of $\mathrm{pH}$ measurements for the glasses investigated. The values plotted are from table 2.

voltage departures (errors) were very large (fig. 2). The reversibility was poor and greatly affected by the immediate previous environment of the electrode, as shown by the data plotted in figure 3 for glasses of 73.63 and 79.50 percent $\mathrm{SiO}_{2}$.

TABLE 2.-Voltage departures (errors) of electrodes prepared from $\mathrm{K}_{2} \mathrm{O}-\mathrm{SiO}_{2}$ glasses of various compositions, using the Beckman glass electrode as the reference electrode

Readings in row (a) were taken in the order of increasing $\mathrm{pH}$, and those in row (b) were taken immediately in the reverse order

\begin{tabular}{|c|c|c|c|c|c|c|c|c|c|c|c|c|c|c|}
\hline \multicolumn{2}{|c|}{ Glass composition } & \multicolumn{13}{|c|}{$\mathrm{pH}$ value } \\
\hline $\mathrm{K}_{2} \mathrm{O}$ & $\mathrm{SiO}_{2}$ & 1.8 & 2.2 & 2.5 & 3.3 & 4.9 & 5.9 & 6.7 & 7.1 & 8.8 & 9.0 & 9.3 & 9.7 & 10.3 \\
\hline$\%$ & $\%$ & $m v$ & $m v$ & $m v$ & $m v$ & $m v$ & $m v$ & $m v$ & $m v$ & $m v$ & $m v$ & $m v$ & $m v$ & $m v$ \\
\hline 28.17 & $71.83\{$ (a) - & & & 23 & 51 & 121 & 198 & 230 & 233 & 311 & & 345 & $-\cdots$ & 375 \\
\hline \multirow{2}{*}{26.37} & (a) - & 0 & 0 & 1 & 0 & 23 & 51 & 76 & 87 & 136 & 142 & 155 & 173 & 196 \\
\hline & ${ }^{3.63}\{(b)$ & -9 & -5 & -4 & -4 & 26 & 57 & 85 & & 147 & 155 & 165 & 173 & 196 \\
\hline \multirow{2}{*}{24.24} & ${ }_{75}{ }_{76} \int(\mathrm{a})$ - & 0 & 0 & 0 & 1 & 14 & 21 & 31 & 34 & 43 & 43 & 53 & 62 & 78 \\
\hline & (b) & -7 & -8 & -8 & -1 & 2 & 11 & 22 & 32 & 51 & 52 & 60 & 61 & 78 \\
\hline \multirow{2}{*}{20.50} & $79.50\{$ (a) - & & 0 & 0 & 0 & 1 & 7 & 13 & 15 & 27 & 31 & 36 & 44 & 62 \\
\hline & $9.00\{$ (b). & -4 & -3 & $|-2|$ & -1 & 6 & 16 & 25 & 29 & 46 & 46 & 50 & 55 & 62 \\
\hline \multirow{2}{*}{16.93} & $83.07\{$ (a) & & 0 & 0 & 1 & 5 & 7 & 13 & 14 & 24 & 26 & 32 & $\ldots$ & 48 \\
\hline & [1 & -16 & -14 & -14 & -7 & 1 & 5 & 6 & 10 & 24 & --- & 28 & $\mid 32$ & 48 \\
\hline \multirow{2}{*}{\multicolumn{2}{|c|}{ Corning 015\{}} & 0 & 1 & 0 & 1 & 1 & 2 & 2 & 1 & 1 & 1 & & -1 & -3 \\
\hline & & 2 & 1 & 0 & 0 & 1 & -1 & -1 & -1 & 0 & 0 & & -1 & -3 \\
\hline
\end{tabular}

Upon comparing the voltage departures for this series of glasses at any chosen $\mathrm{pH}$ values with the percentage compositions, curves are obtained that suggest a sharp change in slope between 74 and 76 percent of $\mathrm{SiO}_{2}$ (fig. 4). An

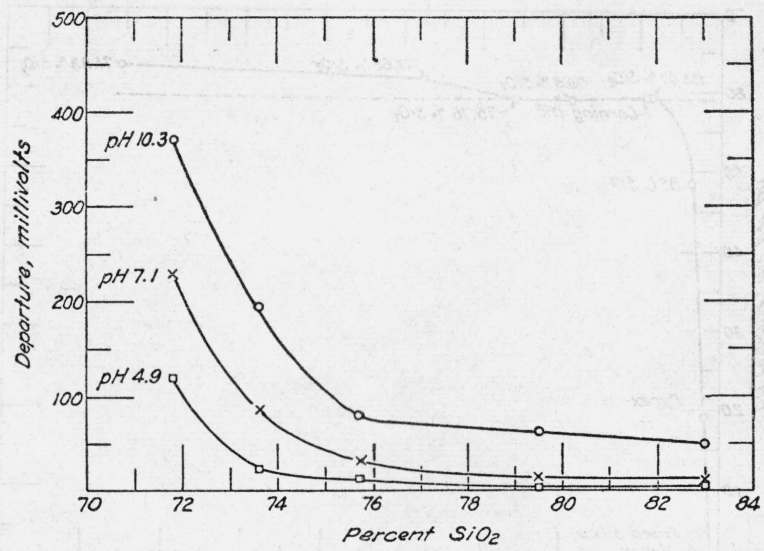

Figure 4-Voltage departures (errors) at $\mathrm{pH}$ values 4.9, 7.1 , and 10.3 for electrodes prepared from the $\mathrm{K}_{2} \mathrm{O}-\mathrm{SiO}_{2}$ glasses.

The values plotted are from the data in table 2 .

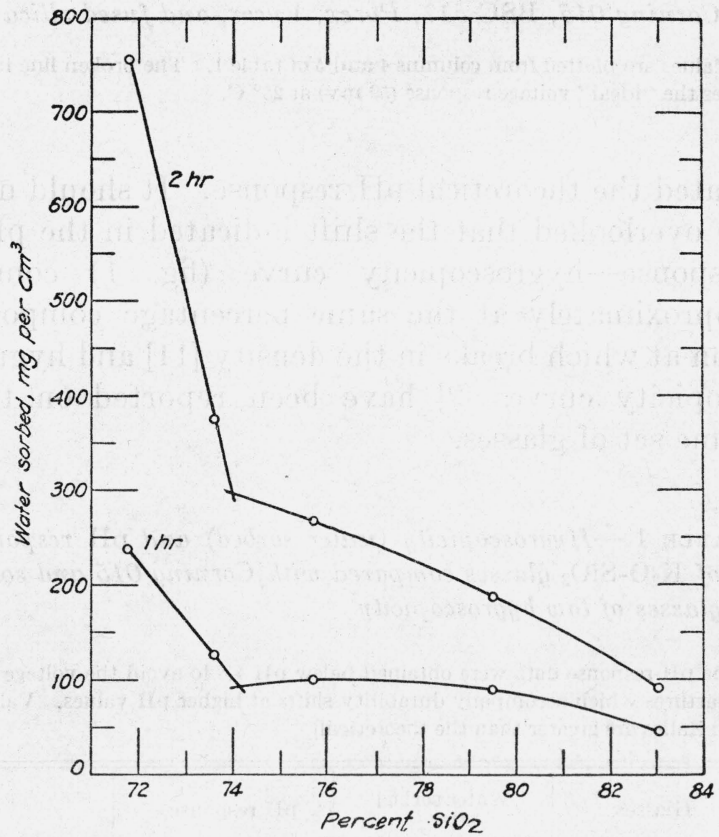

Figure 5.-Water sorbed by $\mathrm{K}_{2} \mathrm{O}-\mathrm{SiO}_{2}$ glasses (hygroscopicity) as a function of the silica content.

Values are plotted from table 1 for water sorbed during 1-hr and 2-hr periods.

abrupt change in properties is indicated also by the hygroscopicity-percentage-silica curves shown in figure 5 , and by a marked change in density $[2,11]$

\section{Voltage Departure With Reference to Chemical Durability and Sodium- Ion Concentration}

Voltage departures from the straight-line relation, exhibited by glass electrodes, have generally been interpreted as an equilibrative response to 


\section{Conclusions}

The results of this investigation further support the belief that glasses of high hygroscopicity (water sorption) will always have sensitive $\mathrm{pH}$ responses and that changes in the durability of a glass will always be accompanied by voltage departures for an electrode prepared from such a glass.

The $\mathrm{K}_{2} \mathrm{O}-\mathrm{SiO}_{2}$ glasses offer little to recommend them for glass-electrode work. Although their hygroscopicity is high, giving them a very sensi- tive $\mathrm{pH}$ response, their durability characteristi are so poor that voltage departures appear $\mathrm{pH}$ values greater than 4.0, even for the be glass (83.07 percent $\mathrm{SiO}_{2}$ ) of the series teste Glasses of higher $\mathrm{SiO}_{2}$ content would be expect to show less voltage departure in the alkali range, but, as the hygroscopicity of the glass 83.07 percent $\mathrm{SiO}_{2}$ is already less than the Corni 015, further increase in $\mathrm{SiO}_{2}$ content would $\mathrm{n}$ result in superior glasses for $\mathrm{pH}$ measurements.

\section{References}

[1] Malcolm Dole, Glass electrode (John Wiley \& Sons, Inc., New York, N. Y., 1941).

[2] Donald Hubbard, Hygroscopicity of optical glasses as indicator of serviceability, J. Research NBS 36, 365 (1946) RP1706.

[3] Donald Hubbard, Hygroscopicity and electrode function ( $\mathrm{pH}$ response) of glasses as a measure of serviceability. J. Research NBS 36, 511 (1946) RP1719.

[4] D. A. MacInness and D. Belcher, Further studies on the glass electrode, J. Am. Chem. Soc. 53, 33153331 (1931).

[5] Donald Hubbard, Edgar H. Hamilton, and Alfred N. Finn, Effect of the solubility of glass on the behavior of the glass electrode, J. Research NBS 22, 339 (1939) RP1187.

[6] Edgar H. Hamilton and Donald Hubbard, Effect of the chemical durability of glass on the asymmetry potential and reversibility of the glass electrode, J. Research NBS 27, 27 (1941) RP1400.
[7] B. Lengyel and E. Blum, The behavior of the gla electrode in connection with its chemical compo tion, Trans. Faraday Soc. 30, 461 (1934).

[8] M. R. Thompson, A metal-connected glass electro BS J. Research 9, 833 (1932) RP511.

[9] Donald Hubbard and Edgar H. Hamilton, Studi of the chemical durability of glass by an int ferometer method, J. Research NBS 27, 143 (194 RP1409.

[10] H. T. S. Britton, Hydrogen ions, 2d ed., table (c), p. 225 (D. Van Nostrand Co., Inc., New Yor N. Y., 1932).

[11] J. C. Young, F. W. Glaze, C. A. Faick and A. Finn, Density of some soda-potash-silica glass as a function of the composition, J. Research N 22, 453 (1939) RP1197.

[12] H. F. Launer, Determination of the $\mathrm{pH}$ value papers, J. Research NBS 22, 553 (1939) RP120

Washington, June 18, 1946. 